\title{
Recovery behavior after matches for returning to training in volleyball athletes
}

\author{
Ananda S. Cardoso, Guilherme P. Berriel, Pedro Schons, Rochelle R. Costa, Luiz Fernando M. Kruel \\ School of Physical Education, Physiotherapy and Dance. Federal University of Rio Grande do Sul.
}

doi: 10.18176 /archmeddeporte.00061

Received: 01/09/2020 Accepted: 04/06/2021

Key words: Heart rate. Physical exertion. Recovery of function. Sports.

\section{Summary}

The aim of this research was to evaluate the behavior of vertical jumps performance in professional volleyball athletes during matches and training and their relationships with fatigue and recovery through heart rate variability (HRV), ratings of perceived exertion (RPE) and perceived recovery status (PRS). Nine male professional volleyball athletes participated in the study, with mean age: $25.66 \pm 5.7$ years, mean body mass: $97.81 \pm 8.65 \mathrm{Kg}$ and mean height: $200.94 \pm 5.19 \mathrm{~cm}$, with experience in national and international competitions. HRV and PRS were evaluated in the morning of matches and in the presentation for the first day of training after matches. RPE was collected immediately after matches and at the end of training days. Jumps performance was monitored during the matches and during the first days of training. The data was grouped by matches and training sessions. Significance level adopted was $a \leq 0.05$. There were no alterations in HRV and PRS evaluated after matches and before training sessions, as well as in RPE after training. Jumps height was greater during the matches $(p<0.013)$ and there were no differences in the number of jumps. There was a positive correlation between the number of jumps during matches and PRS before matches $(r=0.336, p=0.015)$ and a negative correlation between the number of jumps during training and pre-training PRS ( $r=-0.318, p=0.002)$. We conclude that the recovery period proposed by the team proved to be sufficient for the athletes to maintain the same condition for returning to training. This information can assist physical trainers to prescribe training loads for the return to training.
Palabras clave: Frecuencia cardíaca. Esfuerzo físico. Recuperación de función. Deportes.

\section{Comportamiento de la recuperación de atletas de voleibol para el regreso al entrenamiento tras los juegos}

\section{Resumen}

El objetivo de este estudio fue evaluar el comportamiento del desempeño de salto vertical en atletas de voleibol profesional durante juegos y entrenamientos y su relación con fatiga y recuperación por medio de la variabilidad de la frecuencia cardíaca (VFC), calificaciones de esfuerzo percibido (RPE) y estado de recuperación percibido (PRS). Nueve atletas de voleibol profesionales participaron del estudio, con media de edad: $25,66+5,7$ años, media de masa corporal: 97,81 + 8,65 kg y media de altura: 200,94 +5,19cm, con experiencia en competiciones nacionales e internacionales. La VFC y PRS fueran evaluadas en la mañana de los juegos y en la presentación para el primer día de entrenamiento tras los partidos. La RPE fue evaluada luego después del fin de los juegos y al fin de los días de entreno. Saltos fueron monitoreados durante los partidos y durante el primer día de entreno tras los juegos. Los dados fueron agrupados en juegos y sesiones de entreno. El nivel de significancia adoptado fue $a<0,05$. No hubo alteraciones en la VFC y PRS evaluados pre juegos y pre entrenos y en la RPE pos entrenamientos. La altura de los saltos fue mayor en los juegos $(p<0,013)$ y no hubo diferencias para el número de saltos. Hubo correlación positiva del número de saltos de juegos con la PRS antes de los juegos $(r=0,336, p=0,015)$ y correlación negativa del número de saltos de entreno con la PRS pre entreno $(r=-0,318, p=0,002)$. Concluimos que el período de recuperación propuesto por el equipo se ha mostrado suficiente para los atletas mantenerme la misma condición para el regreso a los entrenos. Y esta información ayuda preparadores físicos a planear las cargas de entrenamiento para el regreso a los entrenos. 